\title{
NUMERICAL STUDY ON EFFECT OF A SUSPENDED BOULDER IN SOIL MATRIX ON A DOMESTIC FOUNDATION
}

\author{
Waad Abdulsattar Zakaria \\ College of Engineering, Diyala University, Iraq \\ E-mail: waadzakariya@yahoo.com \\ (Received: 1/2/2011; Accepted:19 /9/2012)
}

\begin{abstract}
Here in this study it is assumed that an undetected large size boulder, has a sharp edge and projecting upwards making a "point force or a point reaction," and exists directly under domestic footing. The beam on elastic foundation (Hetenyi-solution, 1946) will change to different spring constants reflecting soil and boulder strength properties, and in this way the problem is analyzed numerically in FE method using STAAD-Pro/2004 program. The usual stresses and strains existing in concrete footing will eventually change, the case which this study may show. In other words, the study is concerned in the stress distribution in soil with the presence of boulder and in modeling it into the FE method as spring forces, and how these induced forces will change the stresses and strains in the footing concrete by comparing it with the case of non-boulder existence. The integrity of footing is noticed to see how much domestic footing is close to jeopardy. It is concluded that there is high increase in stress over the designed one if there exists a boulder rock underneath footing. In extreme cases these percent stress increase will eventually exceed $100 \%$.
\end{abstract}

Keywords: boulder, soil matrix. Shear stresses, Modulus of subgrade reaction.

\section{A VIEW OF THE PROBLEM}

Boulders are large pieces of rock fractured from the parent material (mother rock) or blown out of volcanoes (bombs). They have volumes ranging from about $1 / 2$ to 8 or even 10 cu.m, in fact soil mechanics books do not put a specified range of size to boulders but yet they are considered as one of the granulometric compositions of soils. Each may weigh in tones and may create disposal or excavation problems on or near the ground surface and problems in soil exploration or pile driving at greater depths when suspended is the soil matrix. Large ones may be suitable to found piles or caissons on, however, size determination may be 
difficult, and placing large load on a small suspended boulder may be disastrous. It is worth to mention here that US-Soil Mineralogy glossary ${ }^{(1)}$ do not put exact size of boulder rock. The rock mass classification mass systems are used for various engineering design and stability analysis. Generally, they are based on empirical relationship between rock mass parameters and engineering applications, such as tunnels, slopes, foundations, and excavatability. The first rock mass classification system in geotechnical engineering was proposed in 1940 for tunnels. The available recent systems for classification are ${ }^{(2)}$, MRMR (mining rock mass rating), NATM (new Austrian tunneling methods, RMR (rock mass rating), the Q-system, and the size-strength classification.

Returning to our problem and for an exaggeration for the problem, a threestorey domestic house is adopted to study. The bearing walls are all made of ordinary masonry work. The ground floor has bearing walls of 14 inches in thickness and height of $4.5 \mathrm{~m}$. The upper two floors consist of bearing walls of 9 inches in thickness and height of $3 \mathrm{~m}$ each, as usually are in the case of domestic houses nationally and abroad. Each floor slab is $200 \mathrm{~mm}$ thick and of reinforced concrete, with tiles of $50 \mathrm{~mm}$ thick. In case of assuming room-bays of 4X4 meters as an average, the load reaching the footing can be calculated in a simple, rough way. In the conditions mentioned before an average of non-factored load equal to $180 \mathrm{kN} / \mathrm{m}$ run of footing is reaching the foundation. Here, a live load of $1.5 \mathrm{kN} / \mathrm{m}^{2}$ is assumed.

\section{WHICH ONE TO USE, MODULUS OF SUBGRADE REACTION KS OR SOIL STRESS-STRAIN MODULUS Es?}

There is some measure of doubt on which of the above variables to use for calculation. According to Bowles (1996) (3) a number of persons do not like to use the concept of a modulus of subgrade reaction; rather they prefer to use $E_{s}$ with $\mu$ (i.e. Poisson ratio) in some kind of the FE. Years of experience have shown that "until a state-of-the-art improves so that accurate values of $\mathrm{E}_{\mathrm{s}}$ can be obtained, the modulus of subgrade reaction is preferable owing to its greater ease of use." Also it has been found out by Bowles that bending moments and computed soil pressure are not very sensitive to what is used for ks because structural stiffness is usually much greater than the soil stiffness as reflected by ks. It is worth to mention here that author himself has indeed checked the effect of $k s$ on $f_{c t}$ (the flexural strength of concrete) for footing in some previous unpublished work and found as well that changing $\mathrm{Ks}$ of soil has rather little effect on $\mathrm{f}_{\mathrm{ct}}$ in non-reinforced concrete footing. 
Nevertheless, and recognizing this fact, Bowles has suggested the two following equations for approximating ks successfully from the allowable bearing capacity qa,

SI: $\quad \mathrm{Ks}=40(\mathrm{SF}) \mathrm{qa}, \quad$ in $\mathrm{kN} / \mathrm{cu} . \mathrm{m}$,

Fps: $\mathrm{Ks}=12(\mathrm{SF}) \mathrm{qa}$, in $\mathrm{kcf}, \mathrm{SF}$ is the safety factor, and qa is furnished in ksf or $\mathrm{kPa}$.

The allowable bearing capacity is based on a settlement of one inch and can be adjusted to any settlement by linear interpolation same as measuring ks.

On the other hand, Wilun and Starszewski (1975) ${ }^{(4)}$ and Teng (1962) ${ }^{(5)}$ stated that the coefficient of proportionality between the applied stress and the settlement at the point of loading on an elastic subgrade is referred as the coefficient of vertical subgrade reaction $\mathrm{Kz}$ (here $\mathrm{kz}$ means ks by Wilun,)

$\mathrm{q}=\mathrm{Kz} . \mathrm{s}$,

where $\mathrm{s}$ is the settlement and $\mathrm{q}$ is the applied stress. The coefficient of subgrade reaction $\mathrm{Kz}$ can also be defined as a stress per unit area that produces a unit settlement at the point of application of the load. They listed the following formula

$\mathrm{Kz}=\mathrm{Es} / \Omega$, where,

$\Omega=\left(\omega \mathrm{B}\left(1-\mu^{2}\right)\right)$

and $E_{s}$ is the elastic modulus of a semi-infinite body; $\omega$ is an influence factor which depends on

-shape of loaded area (here, the footing),

-stiffness of footing in the direction of interest,

-position of the given point with relation of loaded area.

From the foregoing facts, Wilun and Starzewski (1975) ${ }^{(4)}$ concluded that $\mathrm{Kz}$ (or Ks) cannot be considered as a constant for any soil because it depends on shape, dimensions and stiffness of the loaded area. For this reason they did not provide any table relating type of soil with ks.

According to the previous facts, author is satisfied in assuming a direct value of Ks instead of assuming several other strength properties of soil to get an uncertain value of $\mathrm{Ks}$ since there is a measure of doubt for calculating the Ks value. In order to get a presumed value of $\mathrm{Ks}$, author has made use of the ks values presented by Bowles (1996) ${ }^{(3)}$ and Graig $(2004)^{(6)}$ for estimating Ks. Thus a value of $15 \mathrm{MN} / \mathrm{cu} . \mathrm{m}$ (sounds logical) is used for the subgrade reaction of soil which in turn represents either a clayey soil with qu<200 $\mathrm{MPa}$, or medium dense sand (as an average value). Now the vast problem which has floated to surface is the value of modulus of subgrade reaction for the boulder which is suspended in the soil matrix 
underneath the foundation and has projected upwards to form a semi-concentrated vertical force (reaction).

Therefore, how much is the value of $\mathrm{k}$ for this small rock boulder? After comprehensive thinking for the problem, the following two points in concern are drawn;

1- There is no provision in any dependable, standard foundation book (as far as author thinks) which can assume a direct value of the modulus of subgrade reaction for the boulder rock, ksb (here named ksb differentiating it from $\mathrm{Ks}$ ) i.e. the modulus of subgrade reaction which represents the suspended boulder. This is so, because the $\mathrm{k}$ value for soil alone is itself rather difficult to follow, as stated earlier.

2- Author believes that the value of ksb depends on many factors, such as;

-all strength properties of both the boulder rock and the surrounding soil.

-size of the suspended boulder and its extension into the soil depth.

-boulder position in terms of footing.

-and since the boulder is suspended into the soil, it is reasonable to assume that ksb depends very much on Ks.

\section{MEHTODOLOGY TO SIMULATE Ks AND ksb IN A FE MODEL?}

There is an indirect and rather simple method proposed by Bowles (1996) ${ }^{\text {(3) }}$ to deal with the problem of simulating $\mathrm{Ks}$ for a FE model. The Ks value is transformed into a single spring force related to the foundation area. This (big) spring is distributed equally / or not equally into many smaller spring forces working at the interface nodal elements. And since the problem of interest does not involve lateral displacements (perhaps coming from wind or any lateral forces), the Ks in concern here is the vertical Ks only.

\section{ANALYSIS AND RESULTS}

In order to make a reasonable study, we have to minimize the available variables in study so that to concentrate on what we wish. The purpose of this research is to make a comparison study of the stresses developed in footing due to the presence of a large boulder directly underneath the footing, and compare them with the stresses in the case of non-existence of such boulder. So we have the following items to be considered; please care for Figure (1). 
1. The size of footing is; $\mathrm{B}=1.5 \mathrm{~m}, \mathrm{~h}=0.75 \mathrm{~m}, \mathrm{~L}=1 \mathrm{~m}$ (since it is a plane-strain problem).

2. The footing consists of plane concrete having $\mathrm{fc}^{\prime}=20 \mathrm{MPa}$.

3. The applied load is transformed into three (by $60 \mathrm{kN}$ ) concentrated forces working at the three central nodal force points.

4. The footing is modeled with a FE mesh of a plain-strain problem (PSP). It consists of equal square elements having dimensions of $0.15 \times 0.15 \mathrm{~m}$ each, please care for Figure (1). Degrees of freedom in considered only in plain strain in full advantage.

5. $\mathrm{Ks}$ is assumed to be $15 \mathrm{MN} / \mathrm{cu} . \mathrm{m}$ and works as eleven spring reaction forces having each a spring modulus of $2045 \mathrm{kN} / \mathrm{m}$; or working as ten spring forces, each having same spring modulus plus one spring of variable modulus representing the modulus of subgrade reaction of boulder ksb.

6. The location of the boulder is changed in order to have several case studies. The $\mathrm{ksb}$ is put in each case into a different nodal point, thus scanning the whole footing. In this manner, the most critical location causing largest distress to footing can be monitored.

7. Finally, the ratio between $\mathrm{Ks}$ and $\mathrm{ksb}$ is changed to study the effect of this ratio on stresses in footing

It is worth to mention here that the ACI-code stipulates that design stresses in plain concrete pedestals and footings on soil shall not exceed the (1) in flexuralextreme fiber stress in tension $0.42 \Phi \sqrt{ } \mathrm{fc}^{\prime}(\Phi=0.65)$; (2) in shear-if beam action $1 / 3 \Phi \sqrt{ } \mathrm{fc}^{\prime} \quad(\Phi=0.85)$, in two-way action $1 / 6 \quad \Phi \sqrt{ } \mathrm{fc}^{\prime} \quad(\Phi=0.85)$. Also, maximum compressive stress in plain concrete shall not exceed concrete bearing strength, and depth of footing shall not be less than $210 \mathrm{~mm}$. In our situation the maximum tension strength is $1.22 \mathrm{MPa}$ and the maximum shear strength is $1.27 \mathrm{MPa}$. The shear strength here is the beam action since the footing is of domestic type.

In order to illustrate the general trend of the analysis, the aspects of study is summarized as follows,

1. The footing is analyzed as usual without any boulder rock underneath the footing. As said earlier, the modulus of subgrade reaction is assumed $15 \mathrm{MN} / \mathrm{cu} . \mathrm{m}$ and is distributed equally along the foundation nodes.

2. A case of study of one large boulder rock existence is assumed. In order to emphasize its effect on the stresses in footing (in magnitude and propagation), the following approach is follows, 
a. First of all, the effect of boulder rock size is emphasized as assuming multiple values of $\mathrm{ksb}$ in terms of $\mathrm{ks}$ that is, assuming different values of $\mathrm{ksb} / \mathrm{Ks}$, i.e. ratio of modulus of subgrade reaction of boulder rock to that of soil. These ratios are in concern $2,4,6,8,10$ and in addition to two other high ratios of 20 and 30 representing the extreme cases of very large boulder rock. The author insists that these ratios are speculative and may not reflect the reality closely, and only field tests can show the actual ksb/Ks.

b. The location of the bolder is shifted from the footing center line to the edge as to scan the most critical location of the boulder. And as mentioned earlier, the effect of size, strength parameters and stiffness of the boulder is reflected in the ratio of $\mathrm{ksb} / \mathrm{Ks}$.

Nevertheless, it must be said that the obtained stresses as rater low (about 10 to $20 \%$ of the shear and tension strengths of concrete). This is rather an expected result since the footing thickness is $0.75 \mathrm{~m}$ and the applied loads are of domestic regulations. The results of Sxy (the stresses across the $x-y$ plane/ a STAAD designation) is shown in Table (1) and their percentage increase in Table (2). The curves in Figure (2) shows the percent increase of Sxy versus location of the boulder rock, it is simply the drawn data of Table (2). Figures (3) to (8) show the colored contours of stresses for the case of $\mathrm{ksb} / \mathrm{Ks}$ equals 10 where the small black square represents the location of the boulder rock. Observing all stress contours it can be realized that a small zone of maximum stress do occur near the node where the boulder exists, and a zone of "less" maximum stress exists on the other side of the footing. It can be said here that the same trend is observed for all the cases of different values of $\mathrm{ksb} / \mathrm{Ks}$ (noting that it is not practical to show all the stress contour color in study). The foregoing mentioned of facts is something expected and not uncommon, since the concrete in footing is to suffer greater distress in the zone where the boulder rock do exists. The maximum effect of the boulder is about $d / 2$ from the support, i.e. when boulder rock is at a distance of $\mathrm{d} / 2$ from support. And as expected from Table (2) and Figure (2), the higher the ksb/Ks ratio the higher the increase in stress. In worst cases there is a substantial increase in stresses over the normally designed ones of more than $100 \%$ as can be seen in Figure(2). This is a great increase in maximum stresses in case of no boulder exists. So if there is a foundation design with low factor of safety, and with no provision for any boulder existence underneath footing, then the whole structure may be in jeopardy. 
As final analyses, it is assumed that two boulder rocks exist at two opposite sides of footing for $\mathrm{ksb} / \mathrm{Ks}=10,20$, in locations where to give maximum effect. The stress contours are shown in Figures (9) and (10). There are increase in Sxy of 29\% for the case on $k s b / k s=10$, and $50 \%$ in the case of $k s b / K s=20$. As can be seen both results are less than the case of one boulder existence. It must terribly be emphasized here that the probability of existence of such cases (two boulders, one on each side of foundation) is extremely low, but the analysis is conducted here for scientific approaches and also to see how much increase will take place in stresses in such rare cases if it really exists.

\section{CONCLUSOINS}

1- The case of boulder rock existence underneath a foundation is not an uncommon situation. It is probable to some extent that a large stone may exists under pile, domestic footing, or even a multi-storey building foundation. The research is a parametric study. If a boulder is detected initially then many remedial measures can be applied to avoid any stress concentration in concrete footing.

2- The higher the ratio value of $\mathrm{ksb} / \mathrm{Ks}$, the higher percentage increase in Sxy stresses. After boulder distance of approximately $0.5 \mathrm{~m}$ from footing center line the percentage increase in Sxy seems to level off horizontally.

3- It is found that peak stress location is shifted from near footing center to edge of footing as the $\mathrm{ksb} / \mathrm{Ks}$ ratio is decreased

4- The analysis revealed a great increase in the Sxy stresses of about $100 \%$ for the cases of $\mathrm{ksb} / \mathrm{Ks}=20$ and more.

5- Author feel that low ratio of $\mathrm{ksb} / \mathrm{Ks}$ may have no serious effect on the integrity of footing as can be seen in Figure (2). The factor of safety used in design may tolerate this stress increase.

6- The situation of two boulder existence is less sever than one. The probability of such case is very low, yet it has been analyzed for convenience.

\section{REFERENCES}

1- www.stthomas.cdu/geography/soil glossary.htm

2- http//en.wikipedia.org/Rock-mass-classification/wikipedia/The free Encyclopedia/2012.

3- Bowles, Joseph E., (1996), "Foundation Analysis and Design," McGraw-Hill Companies, Inc., USA, 
4- Wilun, Zenon and Starzewski, Krzysztoff, (1975), "Soil Mechanics in Foundation Engineering," Surry University Press, Great Britain.

5- Teng, Wayne C., (1962), "Foundation Design," Prentice Hall, Inc., Englewood Cliffs, N. J., USA.

6- Craig, Robert F., (2004), “Craig Soil Mechanics,” Spon Press, Taylor and Francis Group. London.

Table (1): STAAD values of Sxy in MPa.

\begin{tabular}{|r|r|r|r|r|r|r|}
\hline $\begin{array}{r}\text { Distance } \\
\text { from C.L. }\end{array}$ & $\begin{array}{r}\text { At center } \\
\text { line }\end{array}$ & $0.15 \mathrm{~m}$ & $0.30 \mathrm{~m}$ & $0.45 \mathrm{~m}$ & $0.60 \mathrm{~m}$ & $0.75 \mathrm{~m}$ \\
\hline No boulder & \multicolumn{3}{|c|}{$=0.124 \mathrm{MPa}$ which is the highest value calculated in ordinary case footing. } \\
\hline $\mathrm{ksb} / \mathrm{ks}=2$ & 0.122 & 0.123 & 0.124 & 0.125 & 0.125 & 0.126 \\
\hline $\mathrm{ksb} / \mathrm{ks}=4$ & 0.120 & 0.121 & 0.128 & 0.141 & 0.133 & 0.137 \\
\hline $\mathrm{ksb} / \mathrm{ks}=6$ & 0.117 & 0.131 & 0.157 & 0.165 & 0.153 & 0.156 \\
\hline $\mathrm{ksb} / \mathrm{ks}=8$ & 0.122 & 0.157 & 0.178 & 0.182 & 0.166 & 0.167 \\
\hline $\mathrm{ksb} / \mathrm{ks}=10$ & 0.145 & 0.177 & 0.195 & 0.194 & 0.175 & 0.175 \\
\hline $\mathrm{ksb} / \mathrm{ks}=20$ & 0.213 & 0.237 & 0.239 & 0.225 & 0.197 & 0.192 \\
\hline $\mathrm{ksb} / \mathrm{ks}=30$ & 0.247 & 0.269 & 0.260 & 0.238 & 0.206 & 0.199 \\
\hline
\end{tabular}

Table (2): Percentage increase in Sxy values based on no boulder case.

\begin{tabular}{|r|r|r|r|r|r|r|}
\hline $\begin{array}{r}\text { Distance } \\
\text { from C.L. }\end{array}$ & $\begin{array}{r}\text { At center } \\
\text { line }\end{array}$ & $0.15 \mathrm{~m}$ & $0.30 \mathrm{~m}$ & $0.45 \mathrm{~m}$ & $0.6 \mathrm{~m}$ & $0.75 \mathrm{~m}$ \\
\hline $\mathrm{ksb} / \mathrm{ks}=2$ & -1.6 & -0.8 & Zero & 0.8 & 0.8 & -1.6 \\
\hline $\mathrm{ksb} / \mathrm{ks}=4$ & -3.2 & -2.4 & 3.2 & 13.7 & 7.3 & 10.5 \\
\hline $\mathrm{ksb} / \mathrm{ks}=6$ & -5.6 & 5.6 & 26.6 & 33.1 & 23.4 & 25.8 \\
\hline $\mathrm{ksb} / \mathrm{ks}=8$ & -1.6 & 26.6 & 43.5 & 46.8 & 33.9 & 34.7 \\
\hline $\mathrm{ksb} / \mathrm{ks}=10$ & 16.9 & 42.7 & 57.3 & 56.5 & 41.1 & 41.1 \\
\hline $\mathrm{ksb} / \mathrm{ks}=20$ & 71.8 & 91.1 & 92.7 & 81.5 & 58.9 & 54.8 \\
\hline $\mathrm{ksb} / \mathrm{ks}=30$ & 99.2 & 116.9 & 109.7 & 91.9 & 66.1 & 60.5 \\
\hline
\end{tabular}




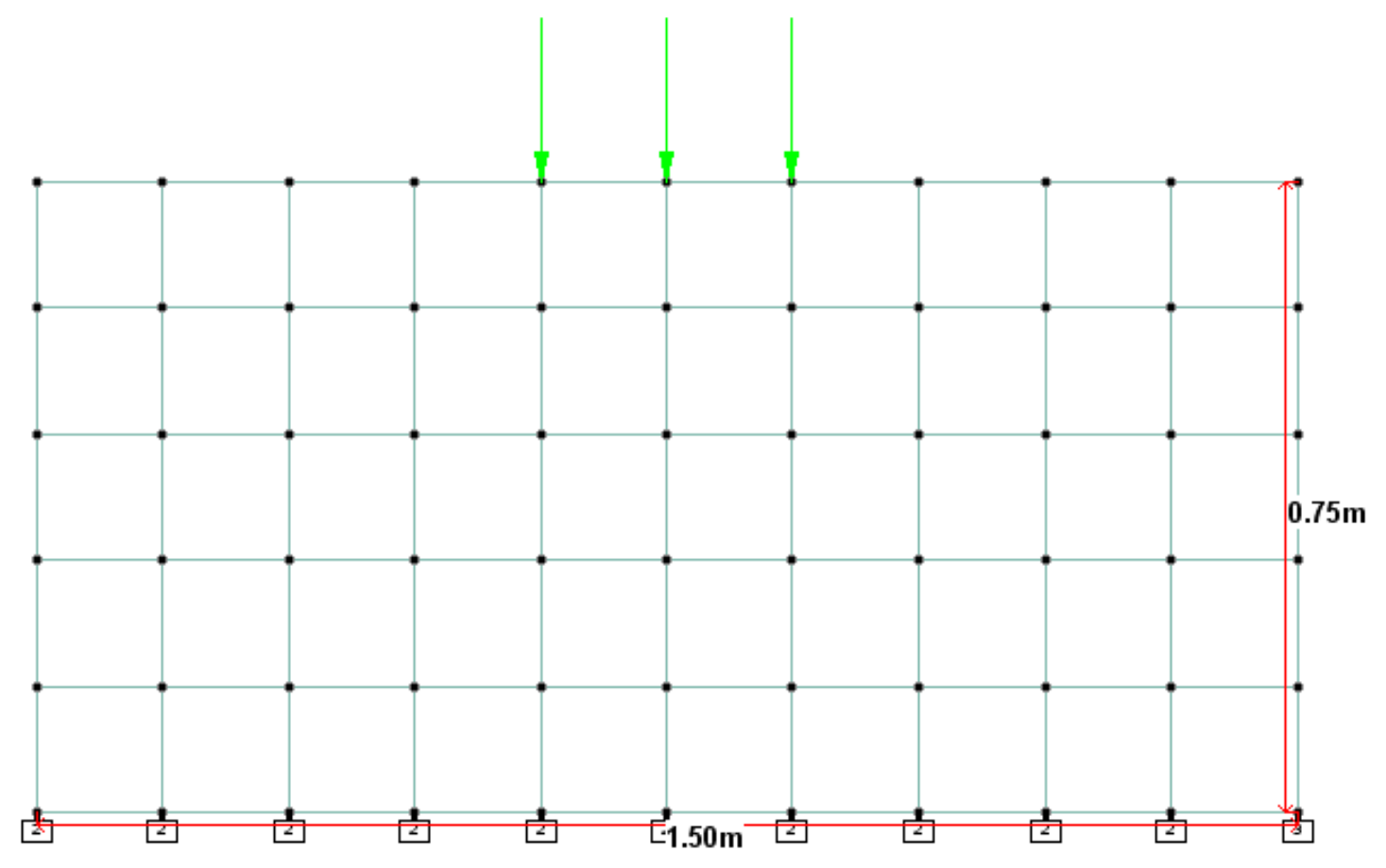

Figure (1): Simple FE mesh used in study.

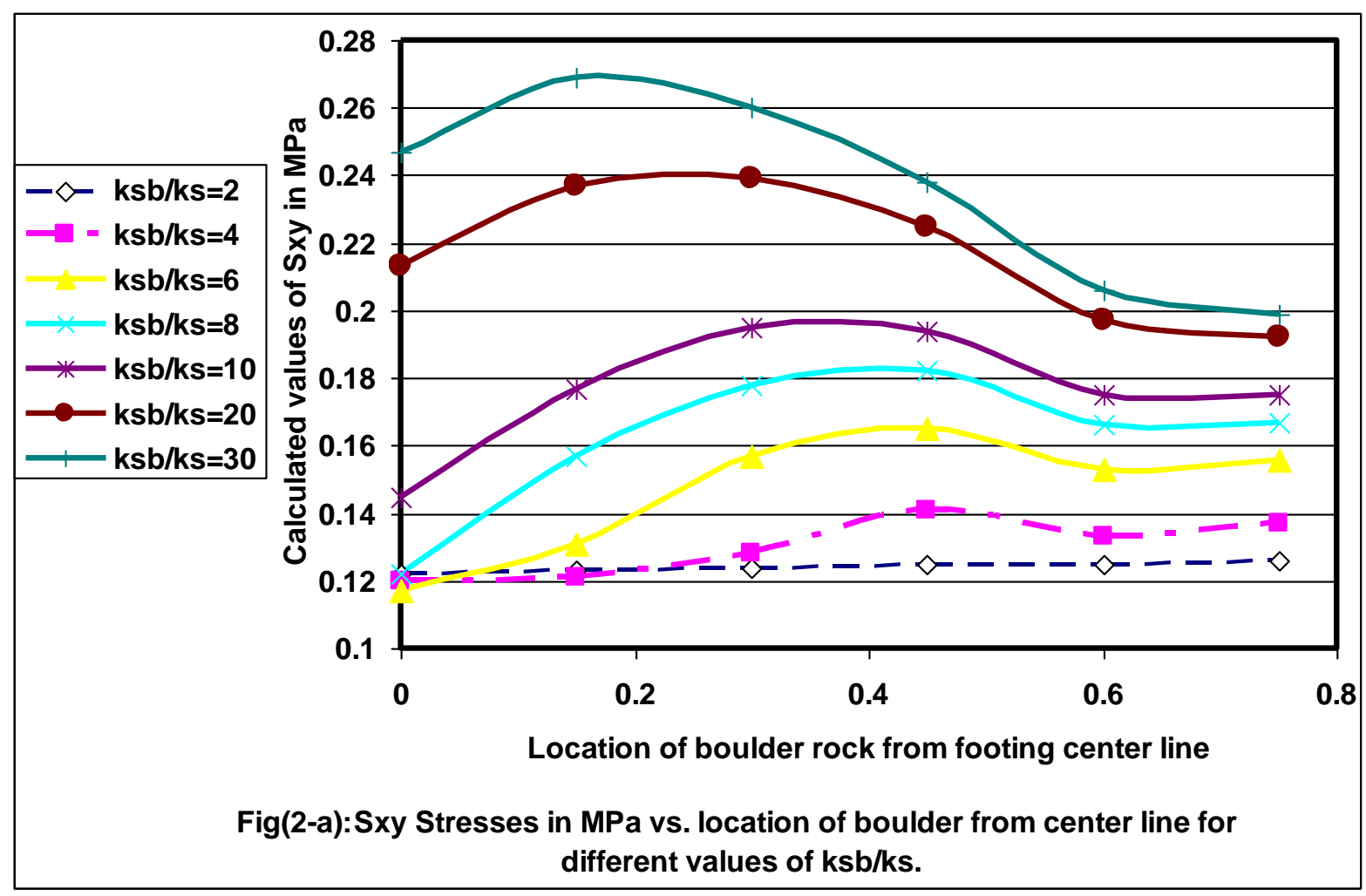


NUMERICAL STUDY ON EFFECT OF A SUSPENDED BOULDER IN SOIL MATRIX ON A DOMESTIC FOUNDATION
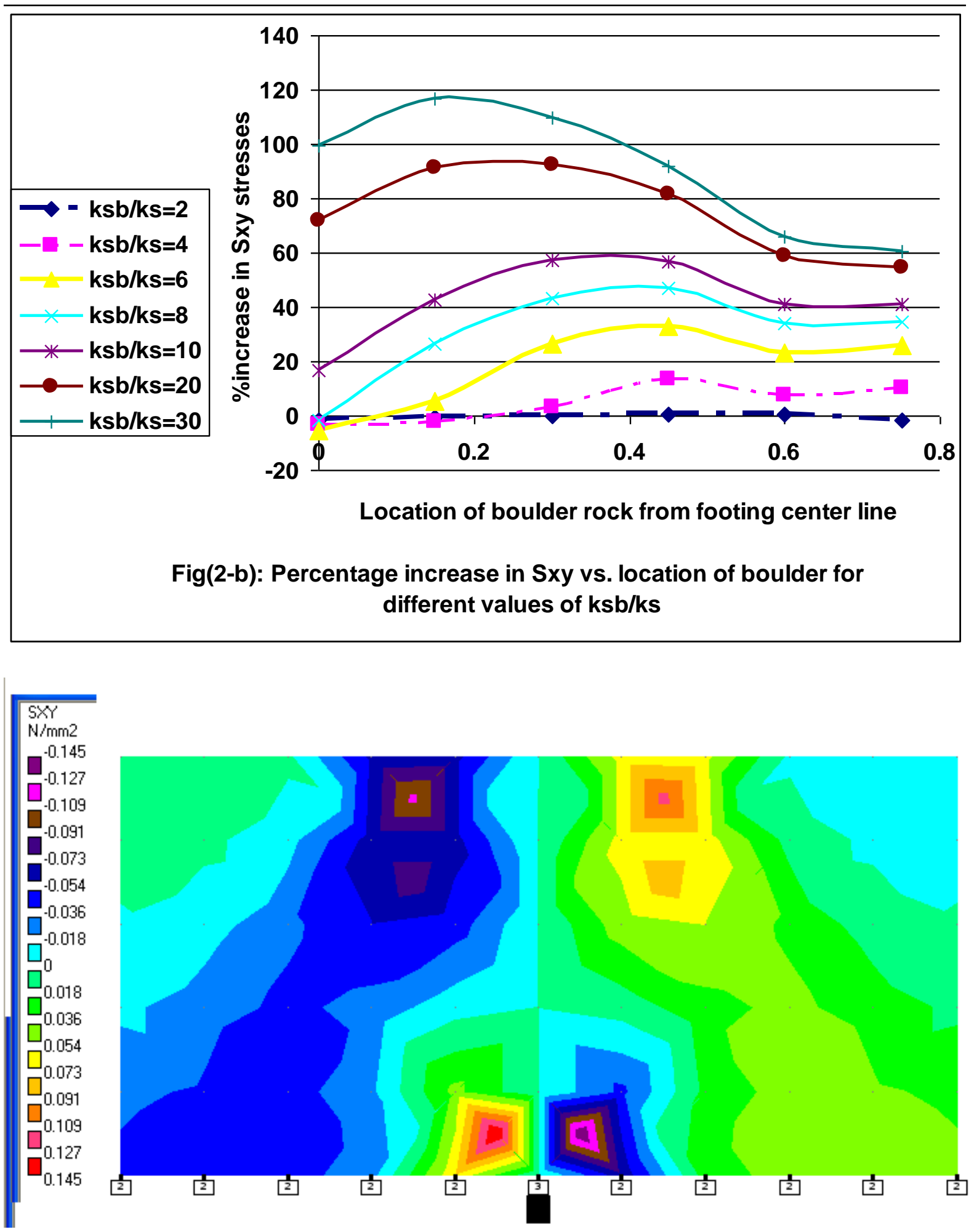

Figure (3): STAAD Sxy stress for $\mathrm{ksb} / \mathrm{Ks}=10$. 

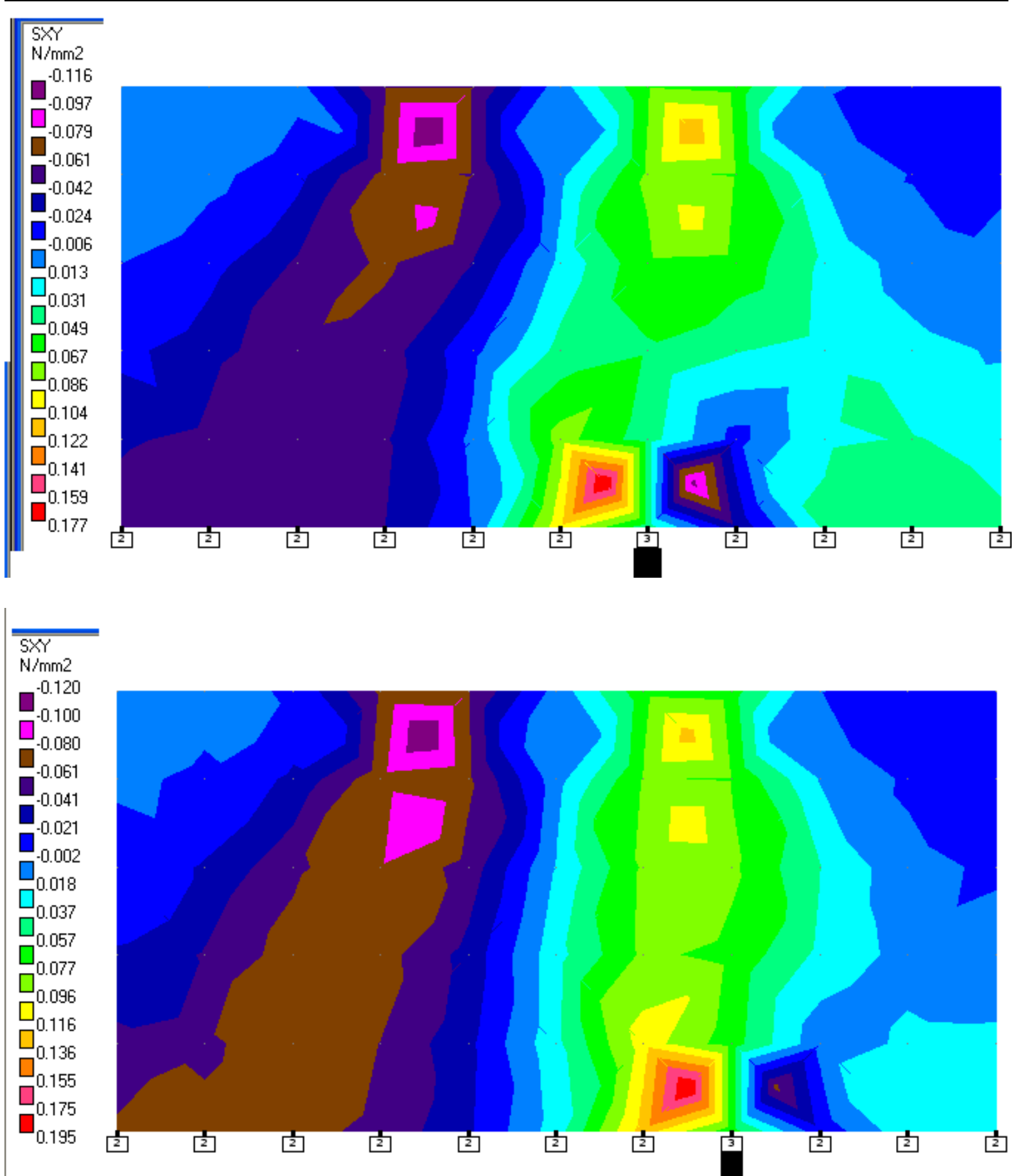

Figures (4 above), and (5): STAAD Sxy stress for $\mathrm{ksb} / \mathrm{Ks}=10$. 

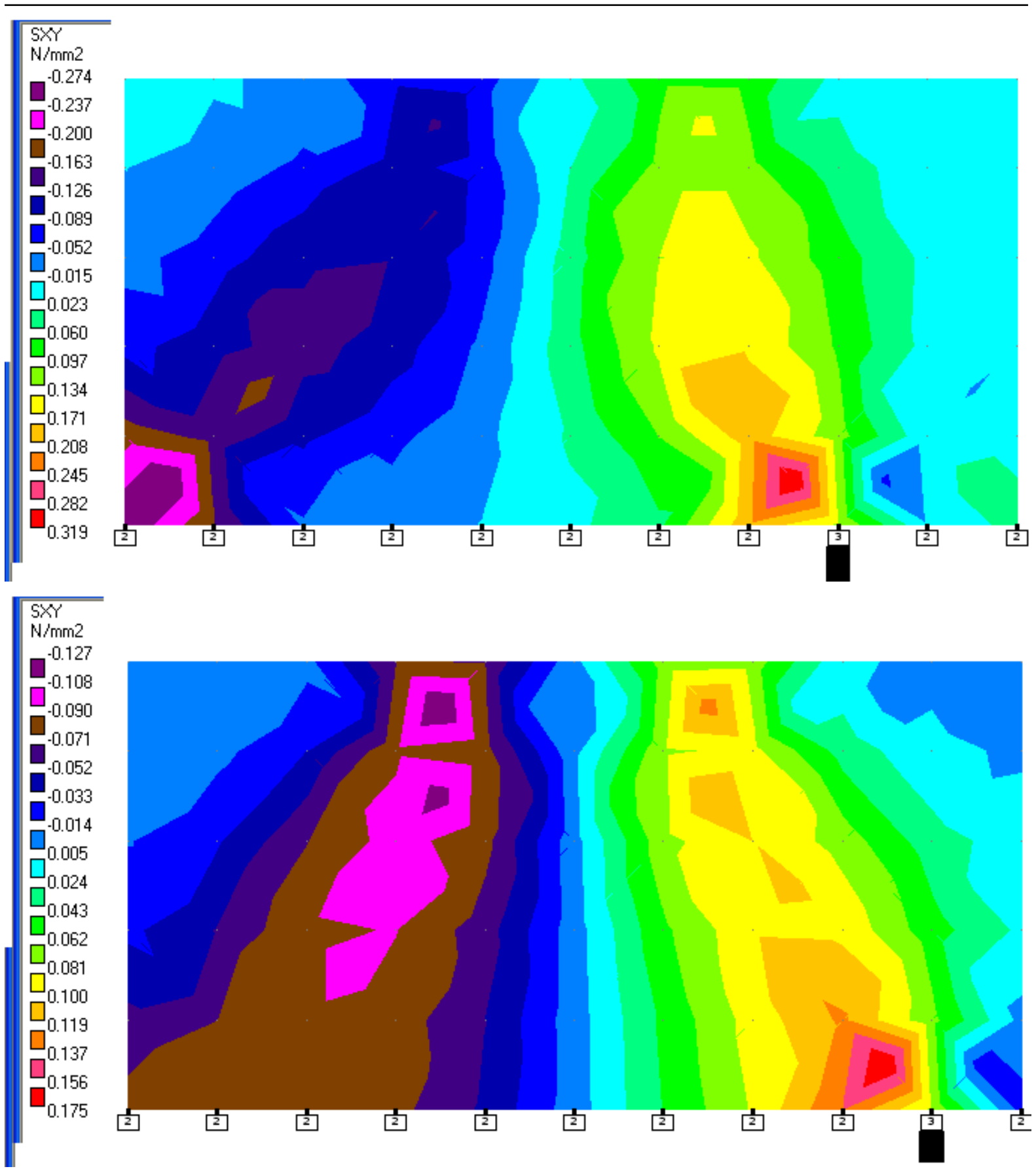

Figures (6 above) and (7): STAAD Sxy stress for $\mathrm{ksb} / \mathrm{Ks}=10$ 
0.175 血

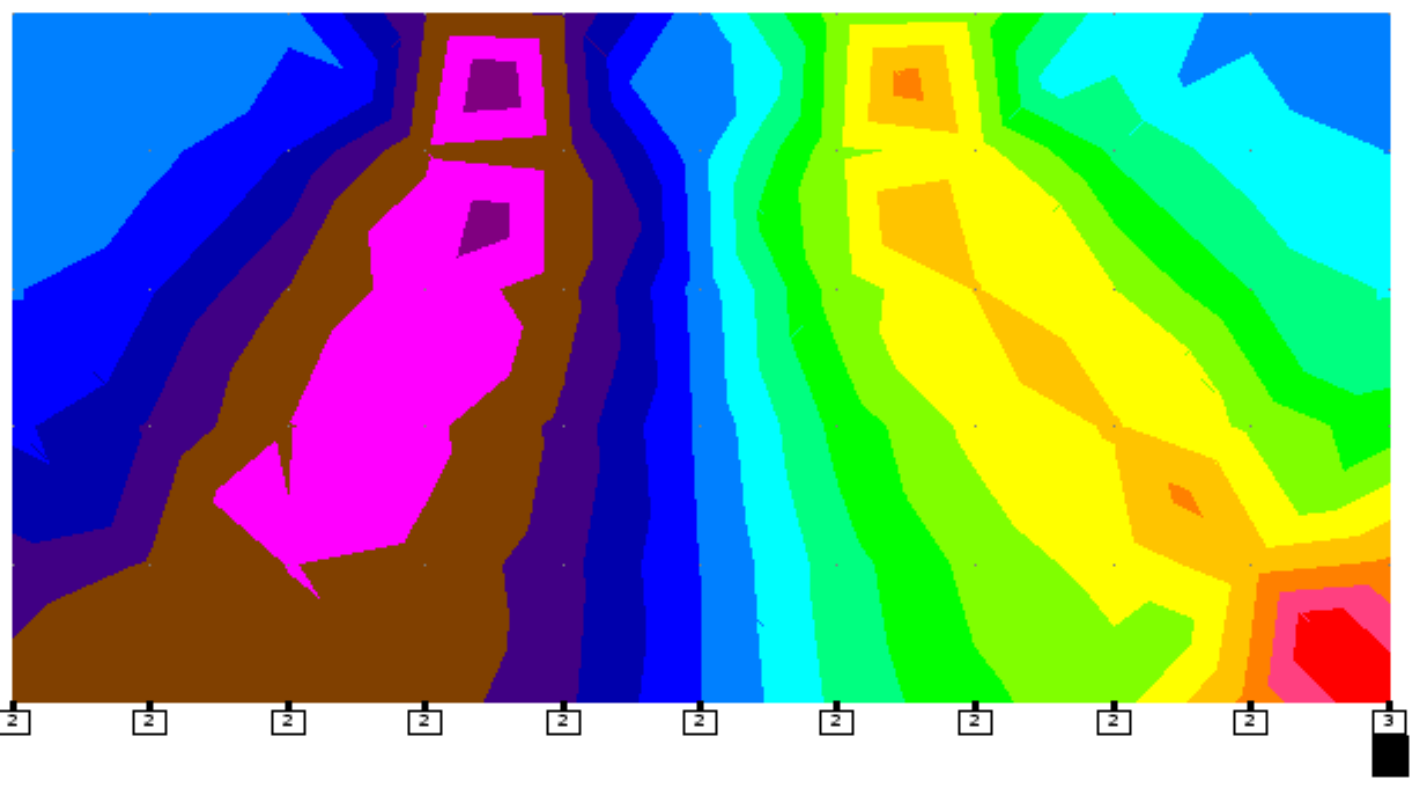

Figure (8): STAAD Sxy stress for ksb/Ks=10.

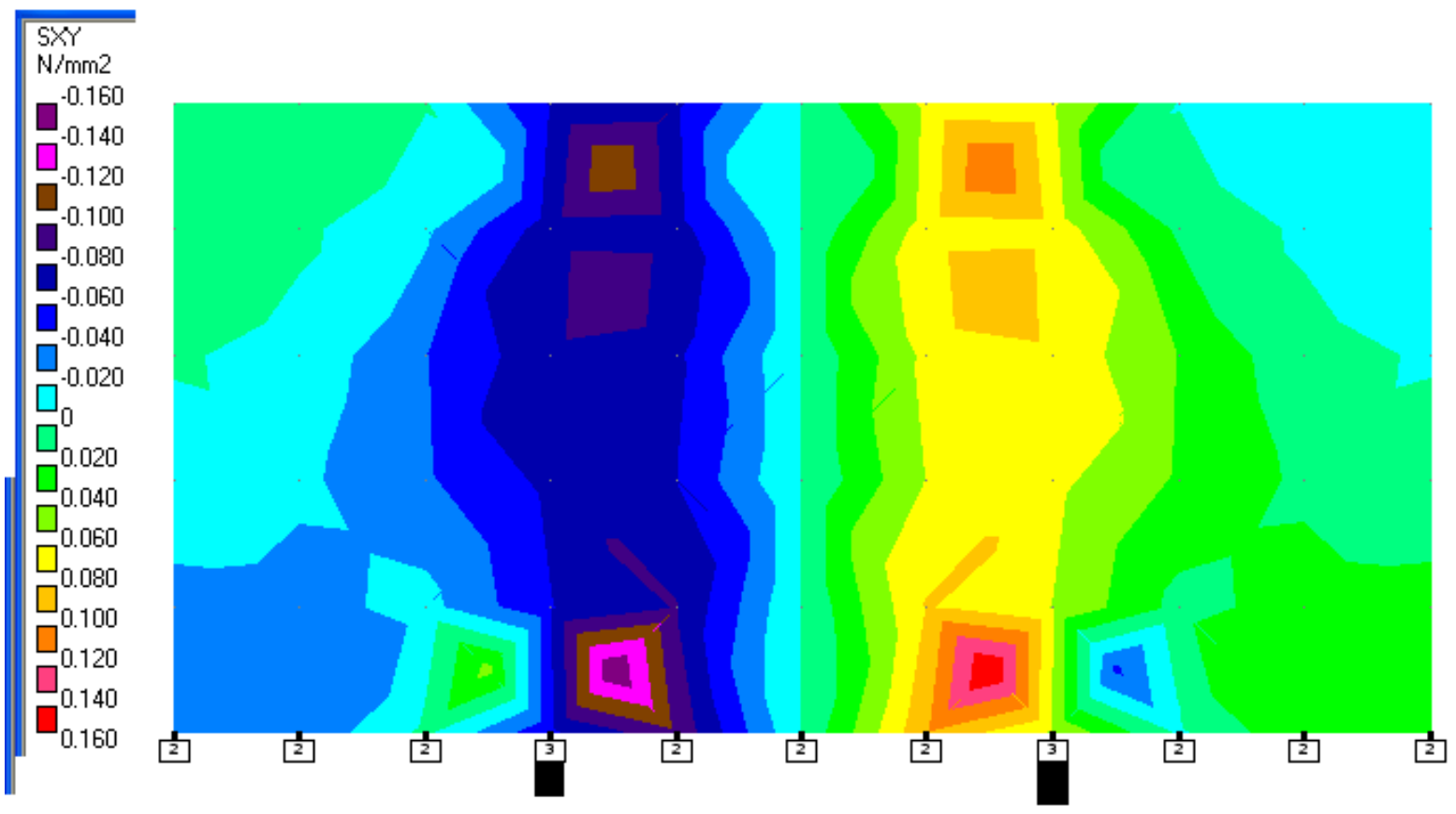

Figure (9): SAAD Sxy stress for $\mathrm{ksb} / \mathrm{Ks}=10$ when there are two boulders at the indicated spots. 


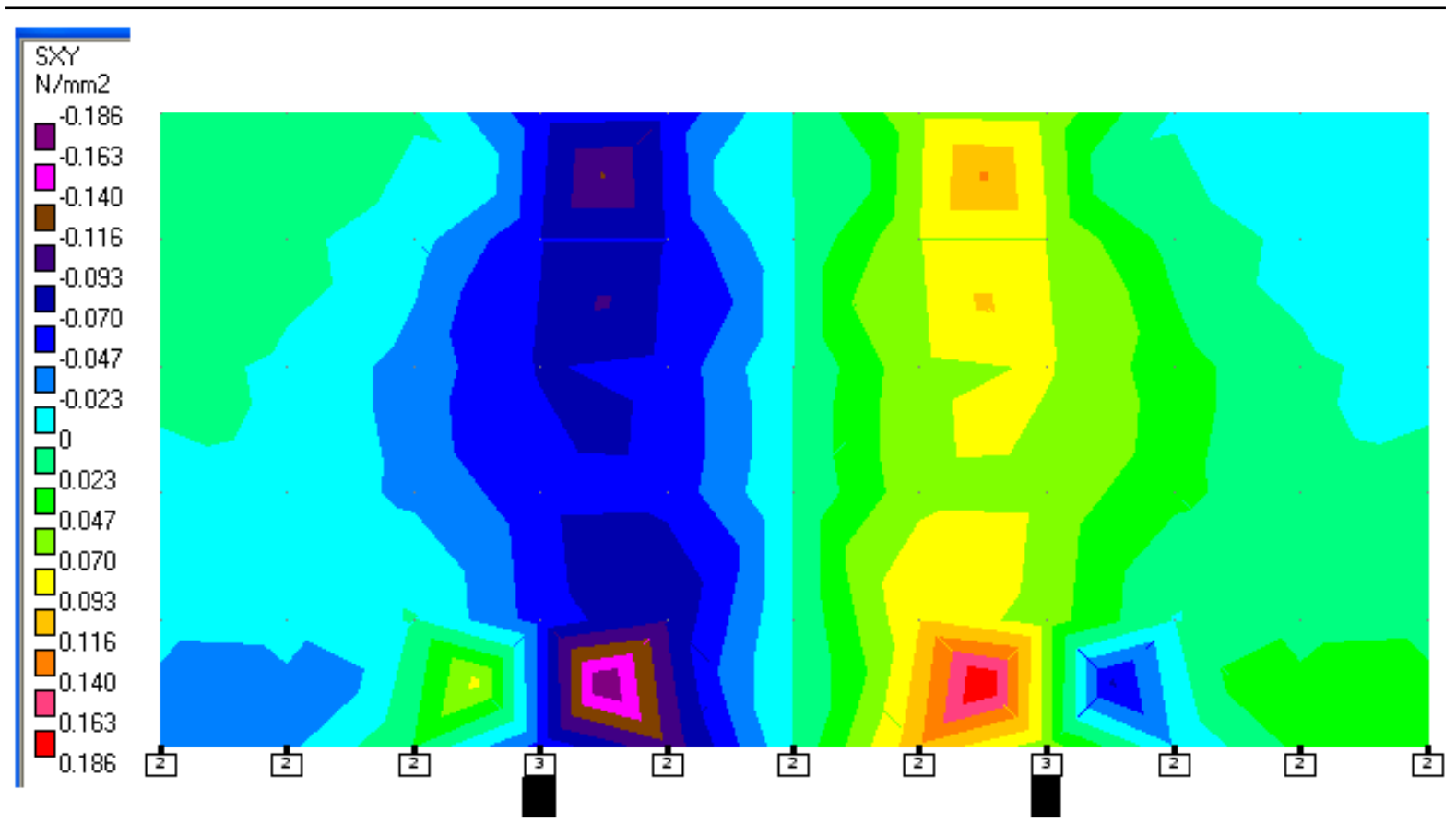

Figure (10): SAAD Sxy stress for $\mathrm{ksb} / \mathrm{Ks}=20$ when there are two boulders at the indicated spots. 


\section{دراسة عددية لتأثير الجلمود المعلق بالتربة على الأسس المنزلية \\ وعد عبد الستار حسين \\ مدرس/ كلية الهندسة/ جامعة ديالى العثار حسن}

الخلاصة

كتعريف جيولوجي إن أحجار الجلمود الصخري عبارة عن قطع ضخمة من الصخور المتكسرة من الصخرة الأم

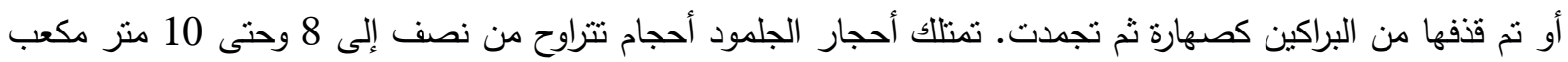
وفي الحقيقة فان الكتب المعتمدة في مكانيك التربة لاتضع مدى ولا مجال لحجم الجلمود ولكن مع ذللك فانه دائما يتم

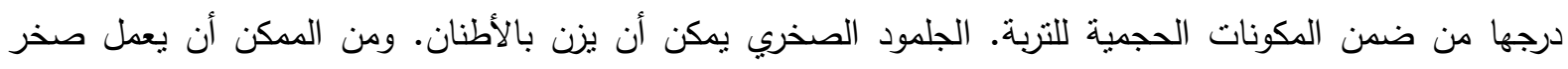

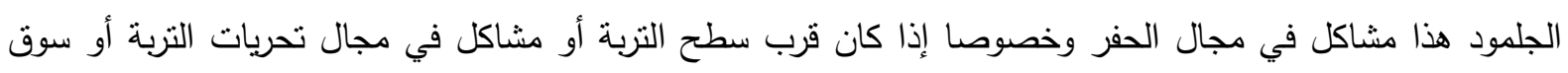

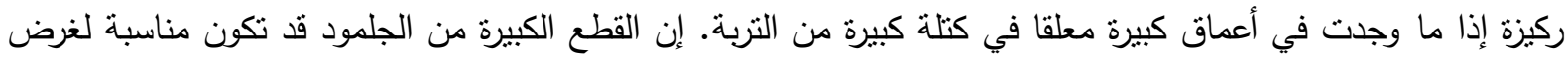

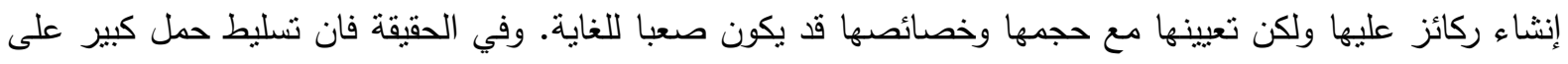

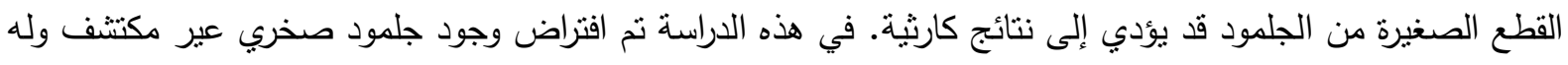
حافة ناتئة إلى الأعلى بحيث تشكل نقطة إسناد أو إسناد نقطي وتوجد تحت أساس منزلي تقليدي. إن نظرية "العتبة فوق

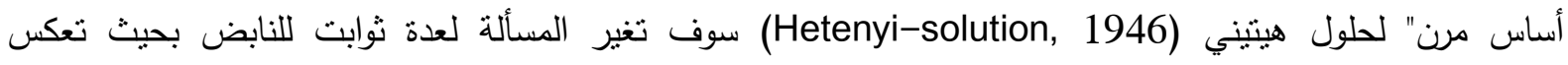
خصائص القوة للتربة والجلمود على السواء. في هذه الدراسة فان المسألة سوف يتم معالجنها عدديا بواسطة نظرية

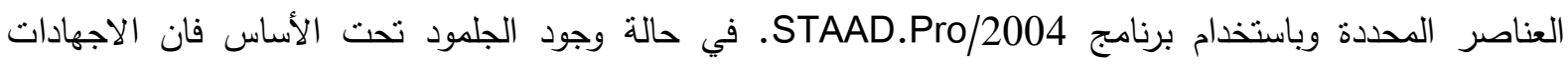
والانفعالات في كونكريت الأساس سوف تتغير في النهاية وهذه الحالة سوف تعكسها الدراسة. أي بعبارة أخرى إن البحث

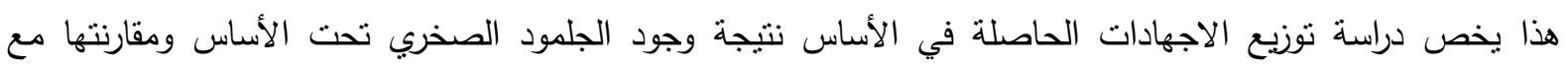

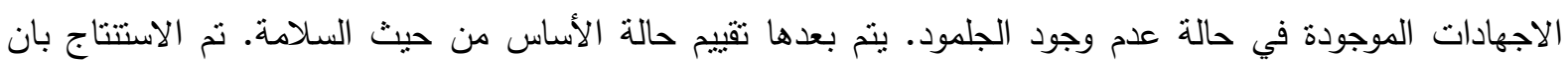

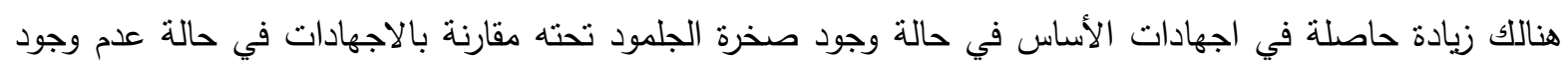
الجلمود. وفي الحالات القصوى فان هذه الزيادة في الاجهادات قد تصل الى 100\% 100ل عند تحليل المسألة تمت معاملتها بطريقة الانفعال المستوي. أما معامل رد فعل الجلمود فقد تم معاملته كضاعف متغير بدلالة معامل رد فعل التربة وهذا كان على أساس افتراضي بحت.

كلمات الادالة: صخر الجلمود, كتنة التربة, اجهادات القص, معامل رد فعل التربة. 